\title{
KETERLIBATAN ORANG TUA DALAM PEMBELAJARAN BAHASA INDONESIA DI MASA PANDEMI PADA SISWA SD NEGERI 02 PENGARASAN KECAMATAN BANTARKAWUNG
}

\author{
Tri Andra Yani ${ }^{1}$, Cintya Nurika Irma ${ }^{2}$ \\ Pendidikan Bahasa Indonesia, FKIP, Universitas Peradaban \\ Email: triandrayani0803@gmail.com ${ }^{1,}$ Cintya_nurikairma@yahoo.co.id ${ }^{2}$
}

\begin{abstract}
Abstrak
Penelitian inibertujuan untuk menjelaskan upaya keterlibatan orang tua dalam pembelajaran bahasa Indonesia di masa pandemi pada siswa SD Negeri 02 Pengarasan Kecamatan Bantarkawung. Sumber data dalam pengambilan data menggunakan wawancara d an ob servasi denga n a nalisis da ta deskriptif. Teknik analisis da ta terdiri dari reduk si data, sa jian data, dan penarikan simpulan. Hasil penelitian menunjukkan bahwa a danya kendala yang dira sakan orang tua dalam pembelajaran bahasa Indonesia pada masa pandemi yang dila kukan secara daring, yaitu: 1) pengaruh pendidikan dan ekonomi orang tua terhadap penggunaan bahasa pertama anak dan (2) belum optimalnya kerjasama yang sinergis a ntara pihak sek olah dan orang tua dalam pembelajaran bahasa Indonesia a nak di rumah, misalnya kunjungan guru ke rumah orang tu a d an penyediaan bahan ajar yang optimal. Adapun u paya yang tela h dilakukan orang tua dalam meningkatkan keterampilan berbahasa Indonesia pada anak yaitu den gan pembinaan bahasa y ang dila kukan orang tua kepada anaknya meliputi(1) pengembangkan kemampuan berbahasa melalui bercerita, (2) berkomunikasi secara aktif di da lam keluarga, (3) mengenalkan dan m embia sakan penerapan kesantunan berbahasa.
\end{abstract}

Kata kunci: orang tua, pembelajaran bahasa Indonesia, pandemi, sekolah dasar.

\section{Abstract}

This study aims to explain the efforts of parents' involvement in learning Indone sian during the pandemic to students of SD Negeri 02 Pengarasan, Bantarkawung District. Sources of data in data collection using interviews and observations with descriptive data analysis. Data analysis techniques consisted of data reduction, datapresentation, and drawing conclusions. The results showed that there were obstacles felt by parents in learning Indone sian during the pandemic which was carried out online, namely: 1) the influence of education and the economyof parents on the use of children's first language and (2) not optimal synergic cooperation between schools and parents in learning Indonesian for children at home, for example a teacher's visit to the parents' house and the provision of optimal teaching materials.

Keywords: parents, Indonesian language learning, pandemic, elementary school.

\section{PENDAHULUAN}

Korona virus yang menyerang kesehatan semua orang tentu menjadi kekhawatiran tersendiri. Social distancing dengan cara tidak boleh berkerumun dengan orang banyak bahkan menjaga jarak fisik (physical distancing) untuk mencegah penyebaran koronavirus senantiasa digaungkan (Dina, 2020). Hal ini menjadikan beragam sektor mengubah sistem atau metode dalam pelaksanaan oprasionalnya termasuk pada sistem pendidikan saat ini. Pembelajaran konvensional secara tatap muka dalam satu ruangan tentu perlu ditinjau ulang pelaksanaannya menjadi kegitan daring (Rahman, 2020).
Kegiatan pembelajaran daring syang dilakukan oleh hampir seluruh institusi pendidikan dengan komunikasi jarak jauh yang tidak lain membutuhkan alat komunikasi seperti telepon genggam, tablet ataupun laptop dan koneksi internet. Sebagaimana yang diungkap oleh Milman (2015) bahwa penggunaan teknologi digital memungkinkan siswa berada di tempat yang berbeda selama pembelajaran, dengan teknologi dapat memudahkan mereka mencari informasi yang luas. Upaya ini dilakukan untuk menjaga keselamatan guru dan siswa dengan pembelajaran yang harus dilaksanakan dengan skenario yang mampu meminimalisisr kontak fisik (Gusti et al., 2020). 
Selain teknologi yang diperlukan, tentu peran orang tua dalam pembelajaran di rumah atau pembelajaran secara daring sangat dibutuhkan agar siswa tetap belajar di rumah. Proses pembelajaran daring yang memerlukan peran orang tua sebagai guru selama siswa belajar di rumah meski terdapat berbagai keleuhan karena orang tua perlu adaptasi mendampingi dan mengajarkan anak serta membagi waktu bagi orang tua yang bekerja.

Selaras dengan penelitian yang dilakukan Cahyati \& Kusumah, (2020) bahwa orang tua dapat meningkatkan hubungan dengan anaknya dan orang tua mestinya dapat melihat langsung perkembangan kemampuan anak dalam belajar di masa pandemi seperti saat ini. Dalam mengajari anak atau mengasuh anak diharapkan orang tualah yang menjadi teladan bagi anakanaknya, misalnya dengan mengajari anak secara sabar dan tekun seperti mendemonstrasikan materi.

Sejalan dengan apa yang dikatakan Rahmawati dalam Djumingin, (2015) mengatakan bahwa pengasuhan anak merupakan sesuatu berkelanjutan melalui proses interaksi orang tua dan anak untuk mendorong pertumbuhan serta perkembangan anak yang optimal. Sama halnya seperti penelitian yang dilakukan oleh Zahra et al., (2020) bahwa dalam pelaksanaan pembelajaran di rumah tentu membawa dampak yang signifikan bagi anak, orang tua maupun guru.

Aktualisasi orang tua dalam memberikan perhatian, motivasi, peran, dan pengawasan kepada anak dalam proses pembelajaran di rumah tentu sangat penting bagi terwujudnya hasil belajar yang optimal. Orang tualah yang harus hadir mengawasi dan memberi perhatian lebih kepada anak, baik pada saat sebelum pembelajaran dimulai, saat pembelajaran berlangsung, sampai dengan pembelajaran selesai. Selain itu, identifikasi kendala yang dialami anak juga dapat diketahui oleh orang tua. Sejatinya proses pembelajaran di rumah, orang tua yang memiliki kewajiban dalam mendidik anak-anaknya dan telah menjadi pondasi pendidikan pertama bagi anak.

Keterlibatan orang tua dalam pendidikan anak usia dini perlu sinergi dengan ragam upaya program maupun kegiatan yang disesuaikan dengan analisis kendala-kendala dari pihak orang tua yang meliputi faktor status sosial, faktor bentuk keluarga, faktor tahap perkembangan keluarga, dan faktor model peran (Irma et al.,
2019). Selanjutnya, pembelajaran di rumah membutuhkan suasana belajar anak yang menyenangkan tanpa ada perasaan tertekan dalam mengaktualisasikan kemampuan dirinya, seperti pada anak sekolah dasar (usia 6-12 tahun) sebagai tahap perkembangan yang fundamental bagi kesuksesan perkembangan selanjutnya.

Sama halnya yang dikatakan Jack dan Logan bahwa anak usia SD mereka secara alamiah memiliki rasa ingin tahu yang kuat, mereka lebih sering bermain, mereka juga belajar secara efektif ketika mereka merasa puas dengan situasi yang terjadi karena mereka belajar dengan cara bekerja, mengobservasi, berinisiatif, dan sudah bisa mengatur dirinya untuk menangani berbagai hal dengan terus mencoba usaha yang baru (Sumartini \& Johariyah, 2009).

Ada beberapa hal yang bisa dilakukan orang tua untuk meningkatkan tumbuh kembang anak dan kesehatan anak, yaitu dengan cara memberi stimulus berupa pemberian cinta yang tulus dan kehangatan, memberi bentuk pengalaman secara nyata dengan menggunakan seluruh indra, melakukan interaksi melalui sentuhan, melalui pelukan, melalui senyuman, nyanyian, mendengarkan dengan penuh perhatian dalam menanggapi ocehan anak, mengajak bercakap-cakap dengan suara yang lembut, dan memberi rasa aman, (Dariyo, 2004).

Orang tua sebagai lingkungan pendidik yang pertama dan utama bagi anak berfungsi sebagai mediator sosial budaya bagi anak. menurut UU NO. 2 Tahun 1989 Bab IV pasal 10 ayat 4: Pendidikan Keluarga merupakan bagian dari jalur pendidikan luar sekolah yang diselenggarakan keluarganya dan yang memberikan keyakinan agama, nilai budaya, nilai moral, dan keterampilan (Lilawati, 2020). Oleh karena itu, orang tua memiliki tugas dalam menyiapkan sarana dan pembentukan kepribadian anak sejak dini.

Kepribadian anak tergantung pada pemikiran dan perlakuan kedua orang tua dan lingkungannya. Salah satu kemampuan atau keterampilan yang harus dikembangkan orang tua dalam upaya keterlibatan orang tua pada pembelajaran di masa pandemi adalah peningkatan keterampilan berbahasa, terutama bahasa Indonesia. Keterampilan berbahasa Indonesia merupakan modal bagi keterampilan di dalam kehidupan. Karena bahasa Indonesia nasional akan mempengaruhi bahasa anak dalam keterampilan berbicara di lingkungannya sendiri. 
Mengingat pentingnya kemampuan bahasa bagi manusia, tidak bisa kita pungkiri bahwa bahasa sangat penting bagi manusia karena memungkinkan seseorang untuk menyesuaikan dirinya dengan lingkungan fisik dan sosial. Melalui bahasa memungkinkan seseorang akan mempelajari kebiasaan, adatistiadat, kebudayaan.

Orang tua hendaknya harus menyadari tugas dan peranannya dalam pembinaan bahasa pada anak walaupun secara alami bahasa seseorang akan mengalami perkembangan, sejalan dengan bertambahnya kenyataan atau pengalaman hidupnya. Seseorang akan mengalami perkembangan dari waktu-kewaktu sesuai dengan bertambahnya usia dan perkembangan intelektual (Mainizar, 2013).

Kemampuan berbahasa tentu tidak diperoleh secara otomatis tanpa usaha-usaha untuk mendapatkannya. (Nursyaidah, 2013). Walaupun hampir semua orang memiliki sarana yang lengkap untuk berbicara seperti mulut, gigi, lidah, dan lain sebagainya, serta memiliki potensi yang diberikan Tuhan kepada manusia. Kemampuan berbahasa diperoleh melalui pengalaman hidup terhadap lingkungannya, mulai dari lingkungan keluarga, sekolah, dan masyarakat. Semakin besar pengaruh yang diberikan lingkungannya semakin besar pula kontribusi bagi peningkatan keterampilan si anak dalam berbahasa.

Sebaliknya, lingkungan tidak akan memberikan kontribusi yang positif bagi perkembangan bahasa anak apabila lingkungan tidak proaktif untuk mengembangkan potensi yang dimilikinya.Jangan sampai seorang anak tidak memiliki keterampilan mengenai kebahasaan terutama dalam hal berkomunikasi menggunakan bahasa Indonesia secara baik dan aktif, dan jangan sampai mereka tidak mengenal betapa pentingnya bahasa Indonesia sebagai bahasa nasional. Seperti pada anak SD Negeri 03 Pengarasan Kecamatan Bantarkawung dalam pembelajaran bahasa Indonesia terutama pada anak kelas VA diantara dari mereka masih belum bisa aktif dalam berkomunikasi menggunakan bahasa Indonesia secara baik.

Ketika pembelajaran di rumah berlangsung tentu orang tualah yang harus membina anak, agar anak selalu aktif dan merasa senang dalam belajar bahasa dengan dasar kemampuan memahami dan mengelola pesan yang diperoleh secara lisan dan tulisan dengan benar. Melalui pembelajaran bahasa Indonesia seorang anak diharapkan selalu senang dan aktif dalam berkomunikasi menggunakan bahasa Indonesia dan mampu memahami fungsi bahasa sebagai sarana komunikasi untuk menyampaikan informasi mengenai sesuatu dalam mengungkapkan pikiran, ide, pendapat, dan persetujuan baik secara lisan maupun tulisan (Kurniah, 2017).

Pembelajaran bahasa Indonesia siswa dapat memenuhi empat aspek kompetensi seperti aspek mendengarkan, aspek berbicara, aspek membaca, dan aspek menulis. Pembelajaran bahasa Indonesia di masa pandemi tentu seorang anak sangat membutuhkan peran orang tua dalam proses pembelajarannya, karena pada hakikatnya dalam pembelajaran bahasa dibutuhkan keterlibatan orang tua yang mampu meningkatkan potensi anak dalam mengembangkan keterampilan bahasa seperti kemampuan dalam berkomunikasi menggunakan bahasa Indonesia dengan baik serta menumbuhkan apresiasi dan sikap positif terhadap bahasa dan sastra Indonesia. Tujuan dalam penelitian ini yaitu untuk menjelaskan bagaimana kendala yang dirasakan orang tua dalam pembelajaran bahasa Indonesia di rumah dan apa saja upaya yang dilakukan orang tua dalam meningkatkan keterampilan bahasa Indonesia pada siswa SD Negeri 02 Pengarasan Kecamatan Bantarkawung.

\section{METODE PENELITIAN}

Metode penelitian yang digunakan dalam penelitian ini adalah metode deskriptif dengan menerapkan analisis kualitatif. Metode kualitatif sebagai prosedur pelaksanaan penelitian untuk menghasilkan data dalam bentuk bahasa deskriptif atau verbal, atau porosedur politik Moleong, (2014). Jenis penelitian ini adalah studi kasus dengan kegiatan yang dilakukan di SD Negeri 2 Pengarasan Kecamatan Bantarkawung pada 26 Oktober 2020. Teknik pengumpulan data yang utama dalam penelitian ini adalah wawancara dan observasi.

Teknik analisis data menggunakan model interaktif dari Miles dan Huberman. Penelitian ini menggunakan triangulasi untuk menguji validitas data. Metode triangulasi yang digunakan adalah triangulasi metode dan sumber dengan memeriksa catatan wawancara, catatan lapangan, angket dan survei. Observasi dilakukan pada orang tua siswa SD Negeri 2 Pengarasan kelas I dengan jumlah 14 anak dan 9 orang tua. 


\section{HASIL DAN PEMBAHASAN}

1. Kendala yang Dirasakan Orang Tua dalam Pembelajaran Bahasa Indonesia di Rumah

a. Status Pendidikan dan Ekonomi Orang Tua Berpengaruh Terhadap Penggunaan Bahasa Pertama Anak

Penggunaan bahasa yang sering digunakan orang tua di rumah atau bahkan di lingkungannya tentu mempengaruhi bahasa anak. Bahasa ibu yang dijadikan bahasa pertama oleh anak melekat pada anak sejak lahir yang biasanya diperoleh dari lingkungan keluarga. Bahasa Ibu yang digunakan setiap saat sring kali terbawa dalam situasi formal yang seharusnya menggunakan bahasa Indonesia dengan baik. Seperti yang terlihat pada sebagian siswa di SD Negeri 2 Pengarasan yang selalu berkomunikasi menggunakan bahasa pertamanya yaitu bahasa Sunda dan ada juga yang berbahasa Jawa ketika mereka di sekolah sebagai bahasa pertama.

Akibat dari penggunaan bahasa pertama yang lebih dominan menyebabkan ketika siswa berkomunikasi dalam situasi formal membuat anak lebih pasif dalam mengungkapkan pendapatnya di depan temanteman lainnya dan ketika proses pembelajaran berlangsung siswa belum lancar menggunakan bahasa Indonesia. Adanya korelasi peran orang tua dengan keadaan pendidikan dan ekonomi terkait penguasaan bahasa Indonesia siswa.

Hal yang dilakukan orang tua dengan pendidikan dan ekonomi yang baik mengajari anak untuk berbahasa Indonesia secara baik bahkan mengundang guru les privat untuk mengajari bahasa anak, baik bahasa Indonesia sebagai pemerolehan bahasa kedua maupun bahasa asing seperti bahasa Inggris sebagai pemerolehan bahasa ketiga anak. Inilah upaya orang tua dalam menumbuh kembangkan keterampilan bahasa anak untuk melanjutkan perkembangan bahasa anak sebelumnya.

Orang tua melakukan pembelajaran bahasa pada anaknya secara baik dan bersungguh-sungguh dalam mendampingi anak demi perkembangannya pembelajaran bahasa yang dilakukan di rumah sudah berjalan efektif ketika guru les privat dan pemahaman orang tua terhadap perkembangan bahasa anaknya semakin meningkat karena sering mengembangkan bahasa kedua mereka yaitu bahasa Indonesia tentu dalam situasi apapun cenderung menggunakan bahasa Indonesia,

\section{b. Belum Adanya Kerjasama yang Sinergis Antara Pihak Sekolah dan Orang Tua dalam Pembelajaran Bahasa Indonesia di Rumah}

Guru memberikan bimbingan dan perhatian kepada semua siswa yang dibimbingnya ketika pembelajaran di rumah yang perlu bekerja sama dengan orang tua yang saat ini bertindak sebagai guru dalam pelaksana pembelajaran di rumah sesuai dengan tugas yang disusun oleh guru di sekolah. Sebagian orang tua siswa SD Negeri 2 Pengarasan mengalami kesulitan dalam mengajari anak terutama dalam pembelajaran bahasa Indonesia karena keterbatasan fasilitas dan sarana dalam menunjang pembelajaran, misalnya penyediaan buku ajar siswa seperti buku keterampilan berbicara anak, buku-buku cerita, dan buku latihan lainnya yang dijadikan pegangan orang tua dalam proses pembelajaran.

Keterbatasan ekonomi menjadikan tidak semua orang tua tidak dapat memfasilitasi memberikan buku bacaan tambahan bagi anak. Selain itu, keterbatasan komunikasi atara guru dan orang tua selama pandemi tidak seluruhnya dapat lancar disebabkan keterbatasan orang tua memiliki seluler atau teknologi yang digunakan sebagai pembelajaran daring dan pertemuan untuk komunikasi langsung pun belum mampu dilakukan karena jaga jarak yang harus dilakukan.

Pihak sekolah menggunakan grup WhatsApp sebagai sarana dalam proses pembelajaran yang dapat dijangakau dan kemudahan dalam menerapkannya, tetapi masih banyak orang tua yang belum memiliki smartphone adapun yang sudah tetapi terkendala dengan jaringan internet. Orang tua yang belum memiliki smartphone terkadang tertinggal mengenai informasi-informasi yang diberikan guru melalui grup WhatsApp, sehingga yang orang tua lakukan bertanya kepada orang tua lain mengenai informasi mengenai tugas apa yang telah diberikan oleh guru. 
2. Upaya Orang Tua dalam Pembelajaran Bahasa Indonesia di Rumah

\section{a. Pembinaan Bahasa Indonesia Pada Anak}

Pembinaan bahasa Indonesia pada anak sebagai motivasi orang tua dalam mengembangkan keterampilan bahasa Indonesia pada anaknya tentu akan mempermudah dan mempercepat kemampuan bahasa anak melalui pembinaan yang dilakukan oleh orang tua secara terarah, terencana, dan berkesinambungan. Dalam pembinaan mengembangkan keterampilan bahasa anak terlihat sebagian orang tua yang selalu mengusahakan agar anak memiliki kemampuan dan kemajuan dalam penggunaan bahasa Indonesia. Adapun upaya yang dilakukan orang tua dalam pembelajaran bahasa melalui pembinaan bahasa Indonesia pada siswa SD Negeri 2 Pengarasan di masa pandemi yaitu:

\section{1) Pengembangkan Kemampuan Bahasa Anak Dengan Bercerita}

Kegiatan yang dilakukan oleh orang tua pada anak SD Negeri 2 Pengarasan yaitu melalui tindakan yang dilakukan orang tua dengan bercerita. Orang tua membacakan cerita-cerita teladan atau hal yang berkaitan dengan dunia anak-anak. Selain itu, orang tua yang selalu berinisatif untuk membeli buku-buku cerita anak dengan kalimat-kalimat pendek dan berilustrasi sehingga anak akan mengembangkan imajinasinya terkait dengan gambar yang dilihat. Setelah orang tua bercerita dan anak mendengarkan orang tua meminta untuk mengulangi cerita yang didengarkan agar anak bisa belajar dalam mengungkapkan apa yang telah dipahami dari cerita tersebut, karena pada perkembangan bahasa anak usia 7 tahun anak lebih senang dalam bercerita menggunakan susunan kalimat dan bahasa percakapan seperti orang dewasa, anak juga senang dalam menulis cerita, misalnya cerita anak-anak yang penuh rekaan, seperti dongeng fabel Si Kancil yang Cerdik, Si Kelinci Yang Sombong dan Kurakura, Kisah Kupu-kupu Yang Ingkar Kepada si Katak, dan lain sebagainya.

Orang tua juga membantu dalam memilih buku yang akan dibelikan atau dipinjam mapupun dimiliki untuk anak. Selanjutnya, orang tua ikut mendampingi dalam membaca dan mempelajari buku yang dipelajari. Percakapan melalui kata-kata yang deskriptif dan selalu mengulangi kata-kata tersebut juga dilakukan karena semakin sering diulangi seorang anak akan mau membaca buku yang sama berulang kali sehingga imajinasi akan semakin terangkai dan memperkaya pemahaman mereka tentang dunia.

Contohnya orang tua yang menceritakan dongeng tentang $\mathrm{Si}$ Kancil Yang Cerdik. Kegiatan bercerita ini akan merangsang imajinasi anak untuk membayangkan kejadian pada tingkah laku hewan yang memiliki sifat cerdik dengan adanya pesan moral yang sekaligus disampikan akan membuat anak berpikir dan belajar untuk menjadi anak yang lebih baik. Begitu pula ketika anak bertanya mengenai kejadian-kejadian pada cerita tersebut tentu orang tua akan menjawabnya hal inilah sebagai pengembangan berbicara anak di dalam proses berkomunikasi.

Orang tua juga membiasakann anak untuk memilih buku cerita lalu orang tua menceritakannya sambil mengajarkan anak untuk membaca cerita akan menjadikan anak merasa bebas, terhibur dengan sendirinya, mengolah imajinasi dengan sendirinya, dan memunculkan berbagai pertanyaan yang biasanya akan dilontarkan kepada orang tua, Komunikasi secara aktif akan berjalan deng an baik ketika orang tua merespons dengan baik dan penuh keaktifan. Aktifitas tersebut mampu mengasah kemampuan membaca, mendengarkan, danmenyiapkan anak untuk memahami kata-kata tertulis.

Kegiatan berikutnya yang dilakukan orang tua yakni meminta kepada anaknya untuk menceritakan terkait pengalamannya bersama teman-temannya atau menceritakan hal-hal lain yang mereka alami atau temui dalam kehidupannya. Hal ini juga akan merangsang anak untuk mengeksplorasi dan menggunakan kosa kata baru yang telah diperoleh selama pembelajaran bahasa di rumah maupun selama perkembangan bahasa sebelumnya.

\section{2) Berkomunikasi Secara Aktif di dalam Keluarga}

Ketika di dalam keluarga terjalin komunikasi secara aktif, tentu hal ini dapat mendukung perkembangan kemampuan bahasa anak. dalam pembelajaran bahasa Indonesia di 
rumah pada siswa SD Negeri 2 Pengarasan, orang tua telah berperan aktif dalam berkomunikasi dengan anaknya, terlihat banyak diantara mereka selalu berkomunikasi dengan anaknya secara menyenangkan ketika berada di rumah, hal ini menimbulkan hubungan yang erat dan hubungan yang hangat sehingga keluargalah sebagai wadah yang baik bagi tumbuh kembang anak, apalagi untuk perkembangan bahasa anak yang secara tidak langsung akan menambah perbendaharaan kata.

Upaya dalam berkomunikasi secara aktif juga dilakukan orang tua melalui aktifitas berkomunikasi dengan lancar dan aktif, serta tidak melarang anak bercerita, tidak menceramahi anak, menekan anak, dan memaksa anak untuk bercerita atau menyampaikan pendapatnya, akan tetapi orang tua membebaskan anak untuk menyampaikan pengalaman atau pendapatnya kapan saja dan di mana saja ketika mereka menginginkannya. Contoh dapat dikaitkan dalam kehidupan sehari-hari, aktifitas yang dijalankan anak ketika mereka berbaur dengan keluaraga maupun temannya ada peristiwa yang dialamai dan merangsang anak untuk bertanya.

\section{3) Mengenalkan dan Membiasakan}

\section{Penerapan Kesantunan Berbahasa}

Pada usia 6 atau 7 tahun anak telah mampu menggunakan kalimat yang lebih kompleks. Motivasi orang tua dalam meningkatkan kemampuan bahasa anak secara berkelanjutan. Seperti yang dilakukan oleh orang tua pada siswa SD Negeri 2 Pengarasan dengan beberapa cara yang dilakukan untuk meningkatkan kemampuan bahasa anak dan mencegah bahasa anak yang tidak santun diantaranya orang tua selalu membiasakan mengucapkan kalimat yang baik dan meluruskan ucapan anak bila ada yang belum tepat agar dasar-dasar penggunaan bahasa Indonesia yang baik dikuasai anak dengan baik.

Orang tua pun telah mengajarkan kata yang sudah diajarkan dengan melatih penggunaannya melalui cara mendengarkan anak berbicara dan menyimak kata-kata yang terlontar dari anak saat berkomunikasi sembari memperbaiki kata-kata yang kurang sopan dan membiasakan bahasa anak yang baik dan benar terhadap lawan tuturnya.
Tindakan orang tua siswa SD Negeri 2 Pengarasan yang membiasakan bertanya kepada anak mengenai peristiwa-peristiwa yang terjadi, karena usia tersebut anak sudah mengenal berbagai peristiwa yang terjadi di lingkungannya. Misalnya ada anak yang bergabung dengan orang dewasa, karena keadaan lingkungan yangdan pergaulan yang kurang mendukung ada orang dewasa yang berkomunikasi secara tidak baik atau tidak sopan, seperti melontarkan kata-kata kasar, misanya kata 'anjay', 'jancuk', 'dodol' dan lain sebagainya, hal ini tentu bisa mempengaruhi anak sehingga anak akan berani melontarkan kata-kata yang seharusnya seusia mereka tidak berhak mendengarkan bahkan melontarkan kata-kata kasar. Karena biasanya apa yang mereka dengar akan mereka ikuti atau tirukan, maka peran orang tua harus memelihara bahasa yang baik misalnya dengan cara bermain dengan anak di rumah, melakukan rekreasi dengan anak, dan mengajak teman-temannya untuk bermain ke rumah, orang tua juga bisa menegur anak secara baik penuh kasih sayang, mengingatkan anak dengan bahasa yang baik, dan memperbaiki bahasa anak dengan bahasa yang sopan.

\section{SIMPULAN}

Keterlibatan orang tua dalam pembelajaran bahasa Indonesia pada Siswa SD Negeri 2 Pengarasan mencakup berbagai upaya yang dilakukan orang tua demi mengembangkan keterampilan bahasa Indonesia pada anak. Hasil penelitian menyimpulkan bahwa pembelajaran bahasa Indonesia di rumah dengan melibatkan peranan orang tua bahwa kegiatan pembelajaran adanya kendala yang dirasakan orang tua dalam pembelajaran bahasa Indonesia yaitu 1) status pendidikan dan ekonomi orang tua berpengaruh terhadap penggunaan bahasa pertama orang tua (bahasa ibu) yang akan berpengaruh dalam penggunaan bahasa anak dan 2) belum maksimalnya kerjasama yang sinergis antara pihak sekolah dan orang tua dalam pembelajaran bahasa Indonesia di rumah seperti penyediaan buku ajar dan kunjungan guru ke rumah peserta didik untuk melihat proses pembelajaran dan perkembangan si anak.

Adapun upaya yang dilakukan orang tua melakukan pembinaan bahasa Indonesia secara baik meliputi: 1) pengembangkan kemampuan berbahasa dengan bercerita, seperti orang tua 
yang membacakan cerita-cerita teladan atau hal yang berkaitan dengan dunia anak-anak. 2) berkomunikasi secara aktif di dalam keluarga demi terjalinnya hubungan yang erat dan hubungan yang hangat sehingga si anak akan selalu aktif dalam berkomunikasi dengan keluarga lainnya, dan 3) mengenalkan dan membiasakan penerapan kesantunan berbahasa dengan cara menyimak dan mengamati kata-kata yang disampaikan anak saat berkomunikasi dan menyampaikan perbaikan kata-kata yang kurang sopan

\section{REFERENSI}

Cahyati, N., \& Kusumah, R. (2020). Peran Orang Tua Dalam Menerapkan Pembelajaran Di Rumah Saat Pandemi Covid 19. Jurnal Golden Age, Universitas Hamzanwadi, 04(1), 4-6.

Dariyo, A. (2004). Psikologi Perkembangan Remaja. Jakarta: Ghalia Indonesia.

Dina, L. (2020). Respon Orang Tua Terhadap Pembelajaran Daring Pada Masa Pandemi Covid-19. Jurnal Ilmiah Pendidikan Islam Anak Usia Dini., 2(1), 46-52.

Djumingin, S. (2015). Model Pembelajaran Bahasa Indonesia Berbasis Lesson Study. In Universitas Negeri Makasar.

Gusti, S., Nurmiati, \& Nurmiala. (2020). Belajar Mandiri Pembelajaran Daring Di Tengah Pandemi Covid-19. Jakarta: Yayasan Kita Menulis.

Irma, C. N., Nisa, K., \& Sururiyah, S. K. (2019). Keterlibatan Orang Tua dalam Pendidikan Anak Usia Dini di TK Masyithoh 1 Purworejo. Jurnal Obsesi : Jurnal Pendidikan Anak Usia Dini, 3(1), 214. https://doi.org/10.31004/obsesi.v3i1.152

Kurniah, N. (2017). Peran Orang Tua dalam Pendidikan Anak Usia Dini Ditinjau Dari Latar Belakang Pendidikan. Jurnal Potensia: Pendidikan Bahasa Indonesia., 2(1), 39-46.

Lilawati, A. (2020). Peran Orang Tua dalam Mendukung Kegiatan Pembelajaran di Rumah pada Masa Pandemi. Jurnal Obsesi : Jurnal Pendidikan Anak Usia
Dini, $\quad 5(1), \quad 549$. https://doi.org/10.31004/obsesi.v5i1.630

Mainizar, M. (2013). Peranan Orang Tua Dalam Pembinaan Dan Pengembangan Bahasa Pada Anak Usia 2-6 Tahun. Marwah: Jurnal Perempuan, Agama Dan Jender, 12(1), 91. https://doi.org/10.24014/marwah.v12i1.5 16

Milman, N. B. (2015). Distance Education. In International Encyclopedia of the Social \& Behavioral Sciences.

Moleong, L. (2014). Metodologi Penelitian Kualitatif. Bandung: Remaja Rosdakarya.

Nursyaidah. (2013). Model Pembelajaran Bahasa Indonesia yang Efektif. Jurnah: Logaritma, I(01), 65-74.

Rahman, S. R. (2020). Pembelajaran Online di Tengah Pandemi Covid-19. Jurnal of Educational of Science, 02(02), 81-89.

Sumartini, S., \& Johariyah, S. (2009). Pembelajaran bahasa indonesia yang nyaman dan menyenangkan dengan metode permainan bahasa. Al-Badiyah, 2(1), 207-230.

Zahra, T., Wardhani, Y., \& Krisnani, H. (2020). Optimalisasi Peran Pengawasan Orang Tua Dalam Pelaksanaan Sekolah Onli Ne Di Masa Pandemi Covid-19 Universitas Padjadjaran. Prosiding Penelitian Dan Pengabdian Kepada Mayarakat, 7(1), 48-59. 
Volume 6 No. 1 METALINGUA

April 2021 Jurnal Pendidikan Bahasa dan Sastra Indonesia 